\title{
Reservoir Characterization of Carbonate in Low Resistivity Pays Zones in the Buwaib Formation, Persian Gulf
}

\author{
Bita Arbab, Davood Jahani, Bahram Movahed \\ Department of Geology, Basic Science Faculty, North Tehran Branch, Islamic Azad University, Tehran, Iran \\ Email: bitaarbab@yahoo.com,d_jahani@iau-tnb.ac.ir,movahed@capegroup.org
}

How to cite this paper: Arbab, B., Jahani, D. and Movahed, B. (2017) Reservoir Characterization of Carbonate in Low Resistivity Pays Zones in the Buwaib Formation, Persian Gulf. Open Journal of Geology, 7, 1441-1451.

https://doi.org/10.4236/ojg.2017.79096

Received: August 1, 2017

Accepted: August 15, 2017

Published: September 29, 2017

Copyright $(9) 2017$ by authors and Scientific Research Publishing Inc. This work is licensed under the Creative Commons Attribution International License (CC BY 4.0).

http://creativecommons.org/licenses/by/4.0/

\begin{abstract}
Carbonate reservoir characterization and estimation of fluid saturation seem more challenging in the low resistivity pay zone (LRPZ). The Lower Cretaceous Buwaib Formation is important reservoir in the Persian Gulf. The formation in the Salman Field is divided into three reservoir zones and four barriers and tight zones. These reservoir zones show low resistivity characteristics, high fluid saturation, but good oil production. In some intervals resistivity responses reach less than $1 \mathrm{ohm} \cdot \mathrm{m}$. Petrophysical properties measured from laboratory and logging tools have been combined with thin section X-ray diffraction (XRD) and PNN (Pulse Neutron Neutron). Geological studies define presence of 8 facies from wackeston to packstone. In general, reservoir potential of the Buwaib Formation is under influenced by the development of lithocodium mound facies that along with moderate to high porosity intervals. Micritization and pyritization of digenetic process along with clay-coated grains, carbonate with interstitial dispersed clay have conspicuous impact on LRPZ. Based on XRD analysis, Montmorillonite and Kaolinite of main clays types have high CEC and greater impact on lowering resistivity. To describe pore systems of rocks, the Lønøy method applied to address pore throat sizes which contain mudstone micro porosity related to lithocodium mound facies and uniform interparticle at class $3 \mathrm{Lucia}$ as pore size varies from 0.2 to 10 micron. Some constraints were defined to estimate reliable water saturation that checked by sigma logs. Water saturation is $42 \%, 34 \%$ and $40 \%$ respectively in BL1, BL2 and BL3 zones.
\end{abstract}

\section{Keywords}

Low-Resistivity Pay, Buwaib Formation, Water Saturation, Clay Types, Pore Systems 


\section{Introduction}

Remarkable hydrocarbon accumulations are "hidden" in the reservoir intervals with low resistivity characteristics, which are known as Low Resistivity Pay Zones (LRPZs). The LRPZ reservoirs were first discovered in a sandstone reservoir within the Gulf of Mexico [1] [2] and then in carbonate layers [3]. These zones are commonly identified with high water saturation based on interpretation of resistivity logs which makes such intervals of low interest to exploration and perforation. LRPZs take place and have reported from both clastic and carbonate reservoirs, in carbonates. It has been reported to be as a result of either or a combination of deep high saline mud invasion, presence of conductive minerals, presence of microporosity, and anisotropic effect due to drilling high angle wells within reservoirs [4] [5]. Typically, LRP zones are characterized by formation interval, with moderate to high porosities, showing extremely low resistivity less than $1 \mathrm{ohm}$ meter. The Buwaib formation and its equivalents host prolific oil reserves in a number of the Persian Gulf countries, particularly in Saudi Arabia, Kuwait, and UAE [6].

\section{Salman Field}

The Salman Field (former Sassan) is an oval-shaped dome structure located 142 kilometers in south of Lavan Island in the Persian Gulf (Figure 1). The Salman structure certainly is the result of salt tectonic. In geophysical maps, presence of faults was detected on the central parts of the structure.

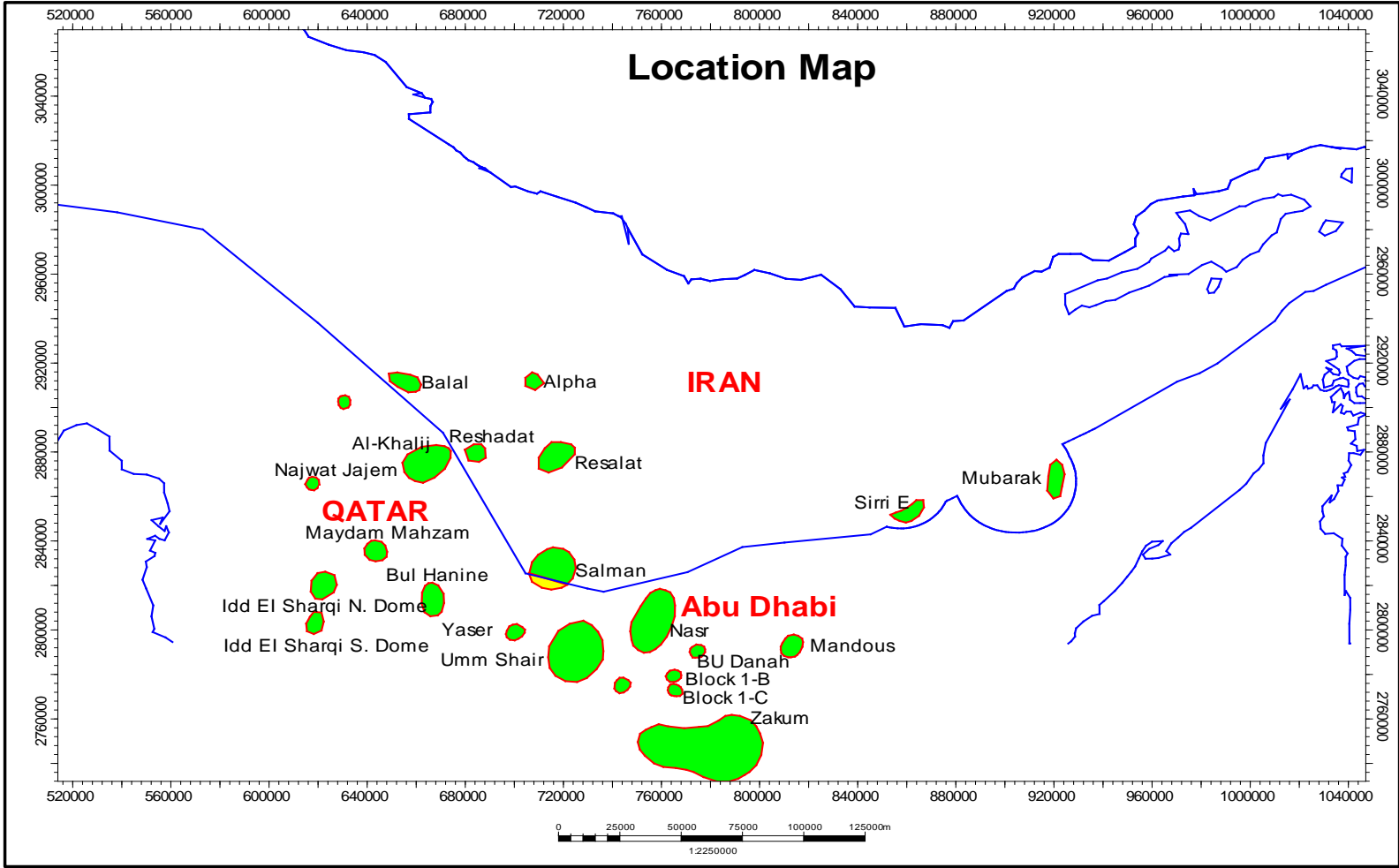

Figure 1. Location map of Salman field in the eastern part of Persian Gulf. 
The field straddles the international border line and is shared between Iran and Abu Dhabi. About 3/4 of the field is within the Iranian border and 1/4 of the field falls in to Abu Dhabi territorial waters which is named Abu Al Bukhoosh (ABK). Oil was discovered by LAPCO in 1965 by drilling the exploration well 2S-1. Tests in the lower Cretaceous Buwaib Formation and the Upper Jurassic Surmeh Formation showed commercial oil. Commercial gas accumulation in Kangan/Dalan and Faraghan Formations was also proved by drilling wells 2SK-1 in 1993 and 2SKD-1 in 2002. The structure of the gas bearing reservoirs is almost circular dome, approximately $19 \mathrm{~km}$ in diameter, and the vertical closure is over $470 \mathrm{~m}$.

\section{Stratigraphical Setting}

The Cretaceous stratigraphic successions the in Persian Gulf are normally divided into three distinct large-scale parts. These major Cretaceous sedimentologic cycles including: 1) the lower Cretaceous consisting of Berriasian to Middle-Late Aptian age sequences; 2) the Middle Cretaceous formed during the late Aptian-latest Cenomanian or earlier Turonian; and 3) the upper Cretaceous which consists of rocks of Coniacian-Maastrichtian age. The lower Cretaceous (i.e., Thamama Group), middle Cretaceous (i.e., Wasia Group), and Upper Cretaceous (i.e., Aruma Group) are designated for the southern Persian Gulf region. The stratigraphical nomenclature in the Salman field generally follows that used in Umm Shaif Field, which situated in $29 \mathrm{Km}$ to the southeast. The total Cretaceous interval in the Salman is $160 \mathrm{ft}$ thinner compared to Umm Shaif. Using gross divisions the upper Cretaceous Aruma dolomites and limestone are almost identical at both locations with $160 \mathrm{ft}$. The Lower cretaceous section is quite similar to that at Umm Shaif. In the middle portion of this zone (Buwaib formation) which suggests that accumulation is properly a function of varying porosity development. The Buwaib carbonates of Salman Field are situated near this locality. Lithologically, the studied formation resembles the Gadvan Formation but its facies types and fossil assemblages (biozones) are similar to the Fahliyan or Yamama carbonates. In the Salman Field, it seems that the Buwaib Formation is a transitional unit between the shale-dominated Gadvan and Fahliyan formations. The lower cretaceous Thamam Group (Buwaib Formation) tested 33 degree API. The Stratigraphy chart of the Persian Gulf and Stratigraphy and Lithology description chart of Salman field illustrates in Figure 2.

\section{Material and Method}

This study is based on combination of petrophysical logs, cores samples $(60 \mathrm{~m})$ and along with 195 thin sections. For clay typing using XRD, 6 samples were analysis to define main clay types of the reservoir. In addition, 150 sample were examined by CT scanning to distinguish main features have a remarkable influence on resistivity response. Core plugs (180 samples) also examined in the Core Lab's for routine and special core analysis. To measure the porosity and permeability, 


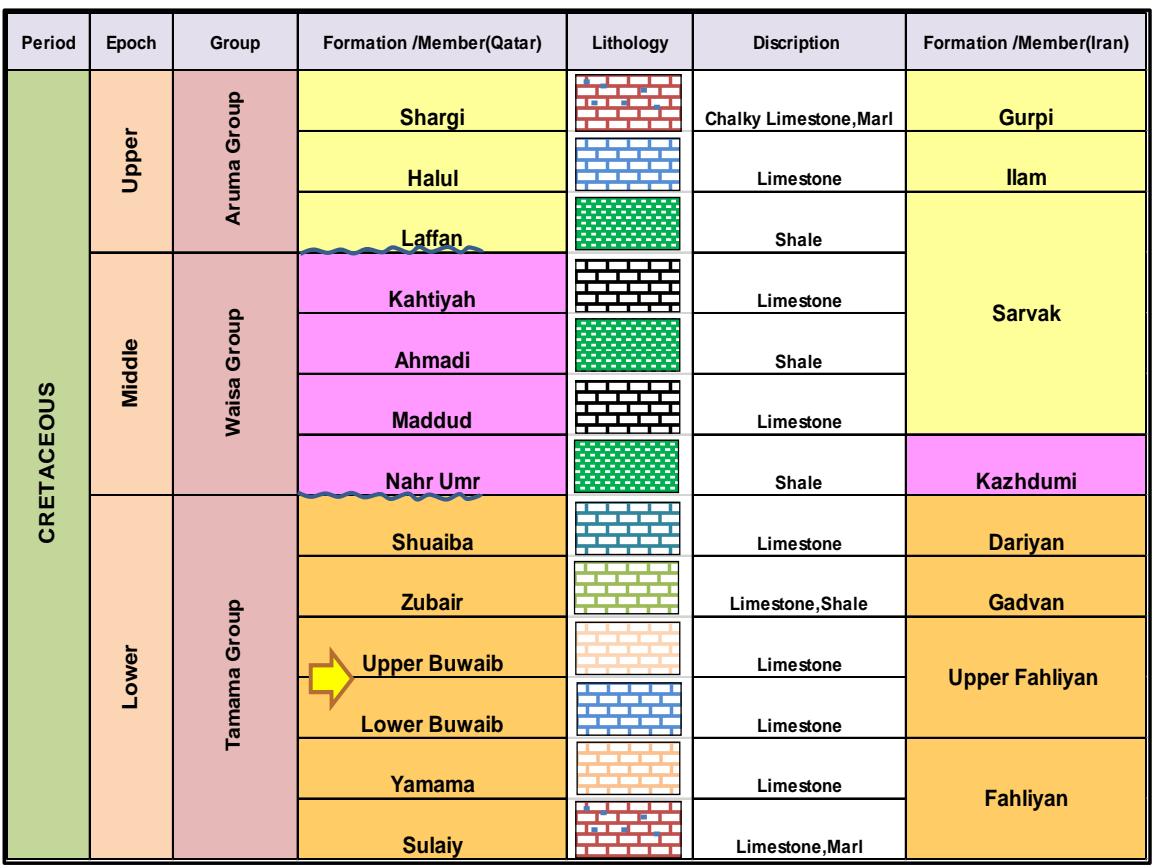

Figure 2. Lithostratigraphic chart of cretaceous units in the Persian Gulf.

all plugs were cleaned by organic solvents (toluene and methanol). Each core plug (1.5 in. in diameter) was tested at ambient condition. In routine core analysis, porosity values are obtained by using Boyle's law.

Thin sections were examined and classified based on their sedimentological and diagenetic characteristics (such as mineralogy, texture, structure, pore system, digenetic features etc.). According to the sedimentological characteristics, facies are defined and interpreted by comparing with the standard facies models. To define pore system classification, Lønøy method (2006) has been used to better combines sedimentologic and digenetic features. In order to determine water saturation in low resistivity pay zone; sigma log and capillary data have been used to address precisely water content.

\section{Depositional Facies}

Petrographic study was performed to elucidate that that reservoir was influenced by various digenetic processes, according to Dunham's classification [7] [8]. In addition, thin sections were described to assess faunal contents and rock textures. Further integration with routine core analysis gave fundamental information on the composition and micro texture of the facies. This also contributed toward understanding the diagenetic overprint and pore systems characteristics of the studied reservoir. Seven microfacies were defined from Wackeston and, Packstone to Floatstone. In these facies, the large benthic foraminifera, diverse algae, and echinoderm are main faunal elements. In addition, peloid, sponge spicule and gastropoda are present. The microfacies consist of including. Foram echinoderm wacke/packstone, Large foram, bioclast wackestone, Sponge spicule, bioclast mud/wackestone, Gastropoda wacke/packstone, Bioclast Packstone/Grainstone, 
Foram, lithocodium float/wackestone, Foram, algal debris wackestone and Peloid Bioclast Packstone. The moderate and high porous zones are lithocodium-bearing facies (MF-5 and MF-6) settled in the upper parts of the reservoir with low gamma ray log indication. In contrast, tight and argillaceous limestone facies (MFs\#1 to 5 and also MF\#7) are present in the lower parts of these cycles and show relatively higher gamma ray readings Figure 3 . The interpreted depositional environment ranged from inner lagoon to inner shoal which it deposited in carbonate platform. Table 1 shows porosity and permeability for each facies as MF 5 and MF 6 contain the best quality of the reservoir.

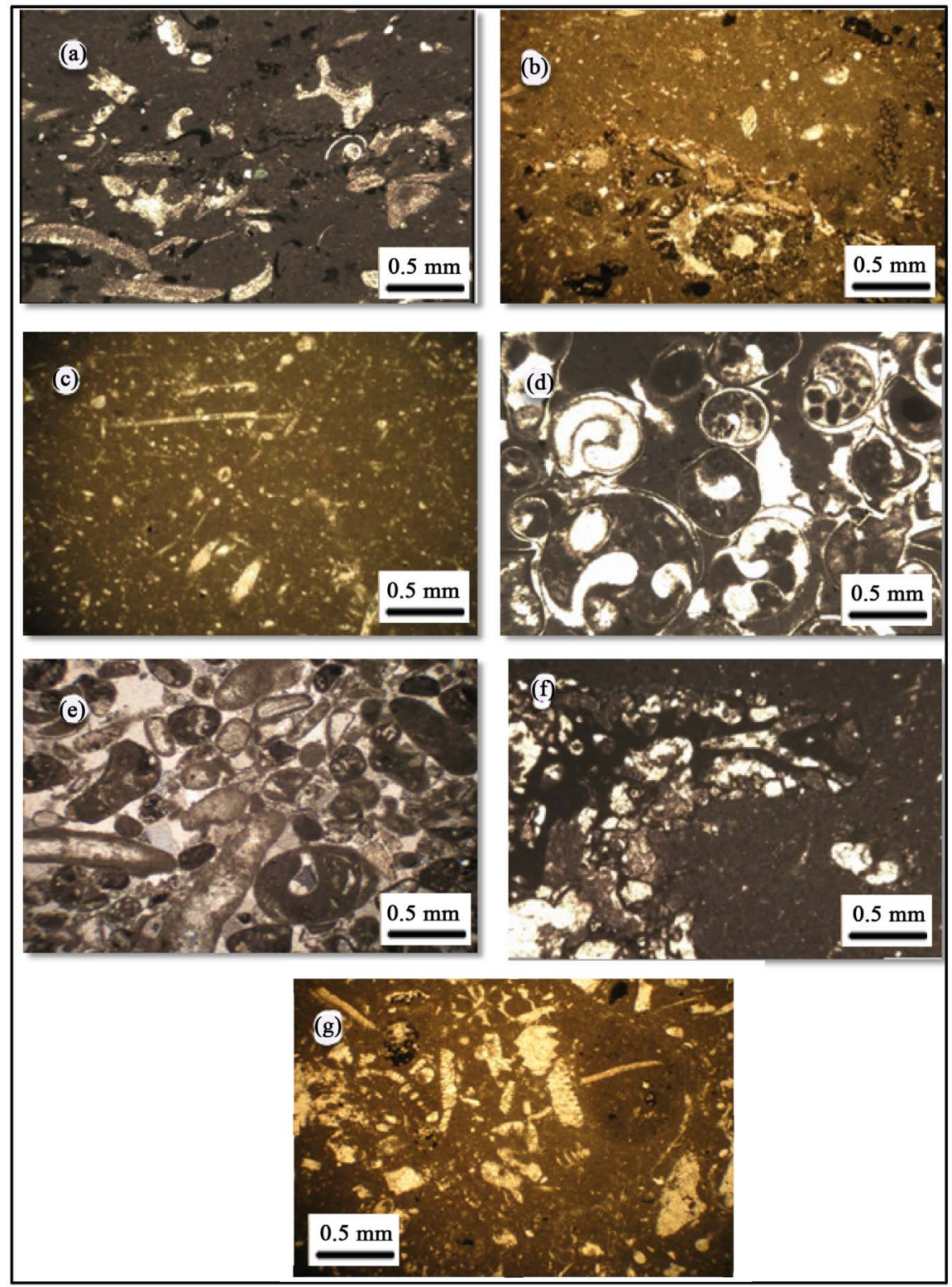

Figure 3. (a) Foram echinoderm wacke/packstone; (b) Large foram, bioclast wackestone; (c) Sponge spicule, bioclast mud/wackestone; (d) Gastropoda wacke/packstone; (e) Bioclast Packstone/Grainstone; (f) Foram, lithocodium float/wackestone; (g) Foram, algal debris wackestone. 


\section{Main Digenetic Feathers on Main Factor for LRPZ Zones}

The identified diagenetic process that took place includes micritization, cementation, replacement (pyritization), and burial compaction. Micritization involved the formation of micrite envelope around the grains, where the porosity and permeability are reduced, by filling the original pore space of the rock. Pyrite mineralization: Paramagnetic minerals such as pyrite have the capability to reduce the log resistivity reading. Their effects vary with their morphology and distribution. Pyrite (FeS2) is present as barrow filling and authigenic-diagenetic mineral (scattered opaque minerals both on the bioclasts and in the rock matrix). It occurs as cubic crystals with fine sizes (less than $0.3 \mathrm{~mm}$ ). Pyritization is also seen in the bioclast grains. Occurrence of pyrite in organic-rich sediments indicate that this mineral may be formed by sulfate reducing bacteria (SRB), under anaerobic condition, although most of the pyrites in sedimentary rocks are of diagenetic origin [8]. Figures 3(a)-(c) and Figure 3(f) show pyritization effect on microfacies.

Micritization: As an earlier diagenetic process, micritization has affected the carbonate grains in the studied formation (Figure 3(a), Figure 3(e), Figure 3(d) and Figure 3(g)). Micritized skeletal fragments are very common in the lagoonal and shoal facies (as reworked grains). Some of the uncertain grains (peloids) have formed during the complete micritization. It seems that after deposition, bioclasts were partially or completely micritized by endolithic and other microbes (micro-borer organisms) on the sea floor. This process commonly occurs in relatively low-energy, shallow-marine environments [8]. In general, various pore types (interparticle, algal voids, bio-molds and fractures) have been completely occluded by calcite spars during diagenesis. In addition, syntaxial cements can be seen over the echinoderm grains. Figure 3(e). It is concluding that Micrites, micritization and pyritization in the studied reservoir occurred on all the identified facies. This suggested a long diagenetic history as early as during deposition and as late as during late burial compaction. High contents of micritic and micritized grains quite along with the low-resistivity response. It was therefore reasonable enough to conclude that the vertical distribution of LRP seen on well logs was as a result of vertical variation of micrites and micritized grains and their history over geological time. Microfacies contain micropores-rich as a result of high contents of micrites.

\section{Clay Types of the Reservoir}

Based on XRD analysis and Thorium, potassium cross plots of petrophysical standard, the reservoir contribute of Illite, Montmorillonite and Kaolinite as main clay types that illustrate in Figure 4.

\section{Pore Type System}

Pore-type classification systems for carbonate reservoirs are limited by the fact that the relation between porosity and permeability is poorly defined. Porosity 


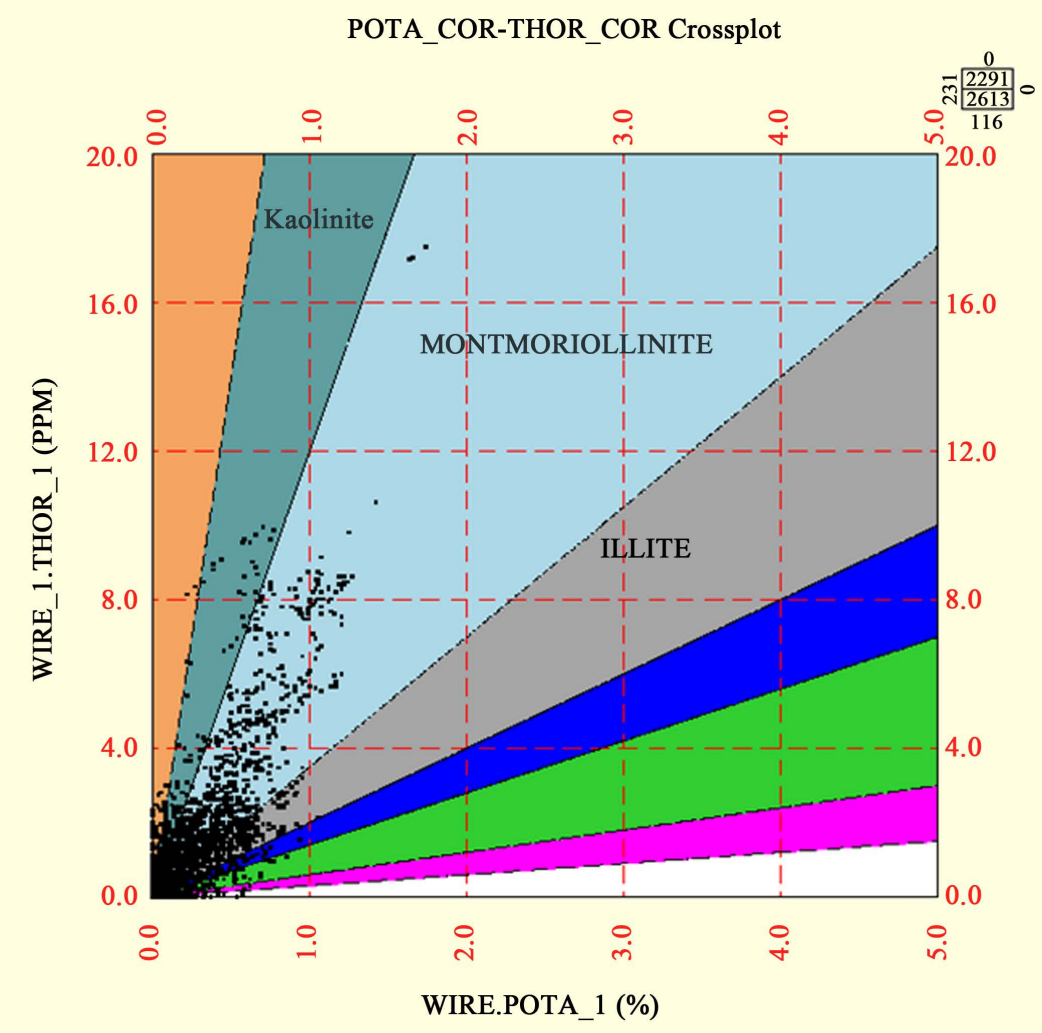

Functions:

feldspar:

glauconite:

Qualitative Feldspar

Qualitative Glauconite.

heavy_th:

illite:

Qualitative Heavy Thorium bearing minerals

kaolinite:

Qualitative Illite.

mica:

Qualitative Kaolinite.

Qualitative Mica.

mont mixed.

Qualitative Montmorillinite \& Mixed Clays.

Figure 4. Thorium and potassium cross plot for clay types. Standard cross Plot shows that is devoted a clay type of mixed Illite, Montmorillonite and Kaolinite for Buwaib formation.

Table 1. Porosity and permeability for each microfacies in LRPZ. It is clear that MF 5 and MF 6 show the best quality of the reservoir and contain high to moderate porosity intervals.

\begin{tabular}{cccccc}
\hline & & \multicolumn{2}{c}{ Arithmetic mean } & \multicolumn{2}{c}{ Geometric mean } \\
\cline { 3 - 6 } Code & Microfacies & $\begin{array}{c}\text { Porosity } \\
(\%)\end{array}$ & $\begin{array}{c}\text { Perm } \\
\mathrm{mD}\end{array}$ & $\begin{array}{c}\text { Porosity } \\
(\%)\end{array}$ & $\begin{array}{c}\text { Perm } \\
(\mathrm{mD})\end{array}$ \\
\hline MF-1 & Foram echinoderm wacke/packstone & 5.405 & 0.118 & 5.109 & 0.02 \\
MF-2 & Large foram, bioclast wackestone & 9.9 & 0.527 & 8.398 & 0.017 \\
MF-3 & Peloid bioclastic pack/grainstone & 10.051 & 1.375 & 7.946 & 0.046 \\
MF-4 & Gastropoda wacke/packstone & 3.557 & 0.295 & 3.257 & 0.007 \\
MF-5 & Sponge spicule, bioclast mud/wackestone & 29.361 & 27.58 & 28.882 & 11.648 \\
MF-6 & Foram, lithocodium float/wackestone & 27.783 & 51.513 & 25.468 & 11.772 \\
MF-7 & Foram, algal debris wackestone & 5.198 & 0.187 & 5.032 & 0.033 \\
\hline
\end{tabular}


distribution is a major new element in the classification. Lucia's and Lønøy subdivision [9] [10] of inter particle porosity has been partly incorporated into the new classification system which is based on pore size instead of grain size and sorting. Lønøy method [9] applied to address pore throat sizes which contain Inter particle uniform microporosity, Chalky Limestone, Mudstone micro porosity. Pore systems are classified at class 3 Lucia and pore size varies from 0.5 to 20 microns. Mudstone micropores have extremely small pore sizes, commonly a few micrometers in diameter, Figure 5.

\section{Petrophysical Interpretation}

The reservoir was divided into 3 units as displayed in Figures 6-8. The wells in the reservoir were drilled with oil base mud (OBM). The wells were cored and logged with full set logging (bulk density, neutron porosity, and resistivity) tools. The reservoir is $81 \mathrm{ft}$. thick; highly heterogeneous with moderate to good porosity as high as $25 \%$, while the permeability ranges from $0.1 \mathrm{mD}$ to more than 11 $\mathrm{mD}$. The resistivity-based saturation log exhibited a water zone. Several approaches utilized to model the water saturation.

Using Full set logs and Sigma log with defining some constraints petrophysical parameters led to define water saturation Figure 6. The computed log saturation showed high water saturation; however, other data indicated the presence of hydrocarbon (e.g., mud logs and pressure gradient). For this study, the calculation of water saturation using sigma log was done using the following equation Figure 7.

$$
\mathrm{SW}=\left(\left(\sum \log -\sum \mathrm{M}\right)-\varnothing\left(\sum \mathrm{H}-\sum \mathrm{M}\right)\right) \div \varnothing\left(\sum \mathrm{W}-\sum \mathrm{H}\right)
$$

where $\varnothing$ is porosity, $\sum \log$ is formation sigma capture cross section log reading, $\sum M$ is matrix sigma capture cross section log reading, $\sum M$ is hydrocarbon sigma capture cross section $\log$ reading, $\sum \mathrm{W}$ is formation water

Lucia, interparticle class 3

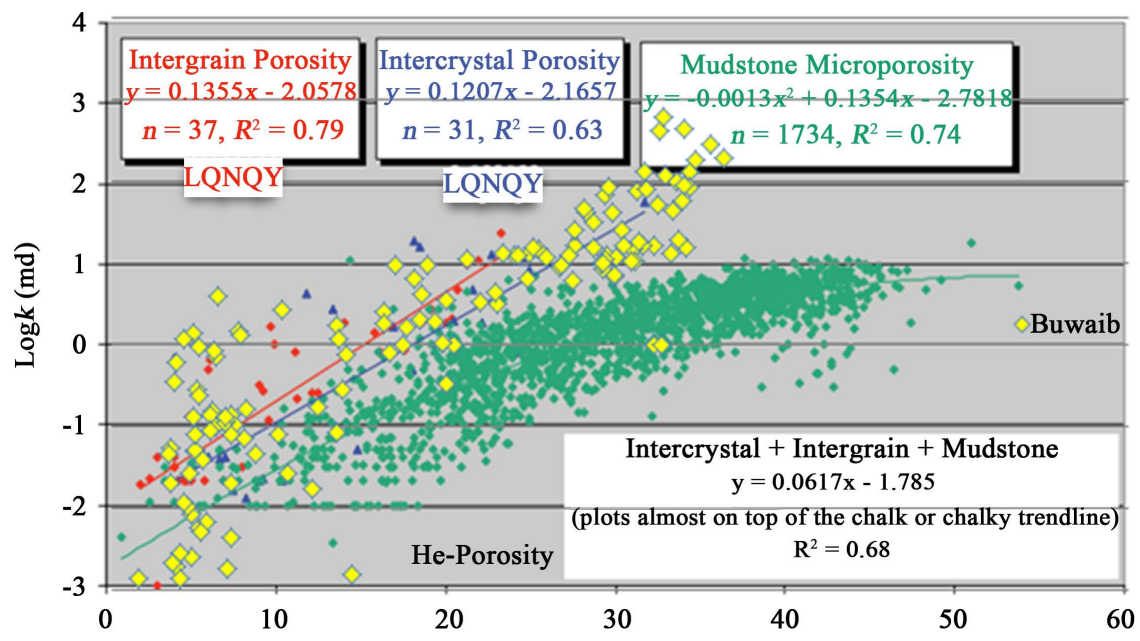

Figure 5. Pore systems of Buwaib formation in interparticle micro uniform pores. 


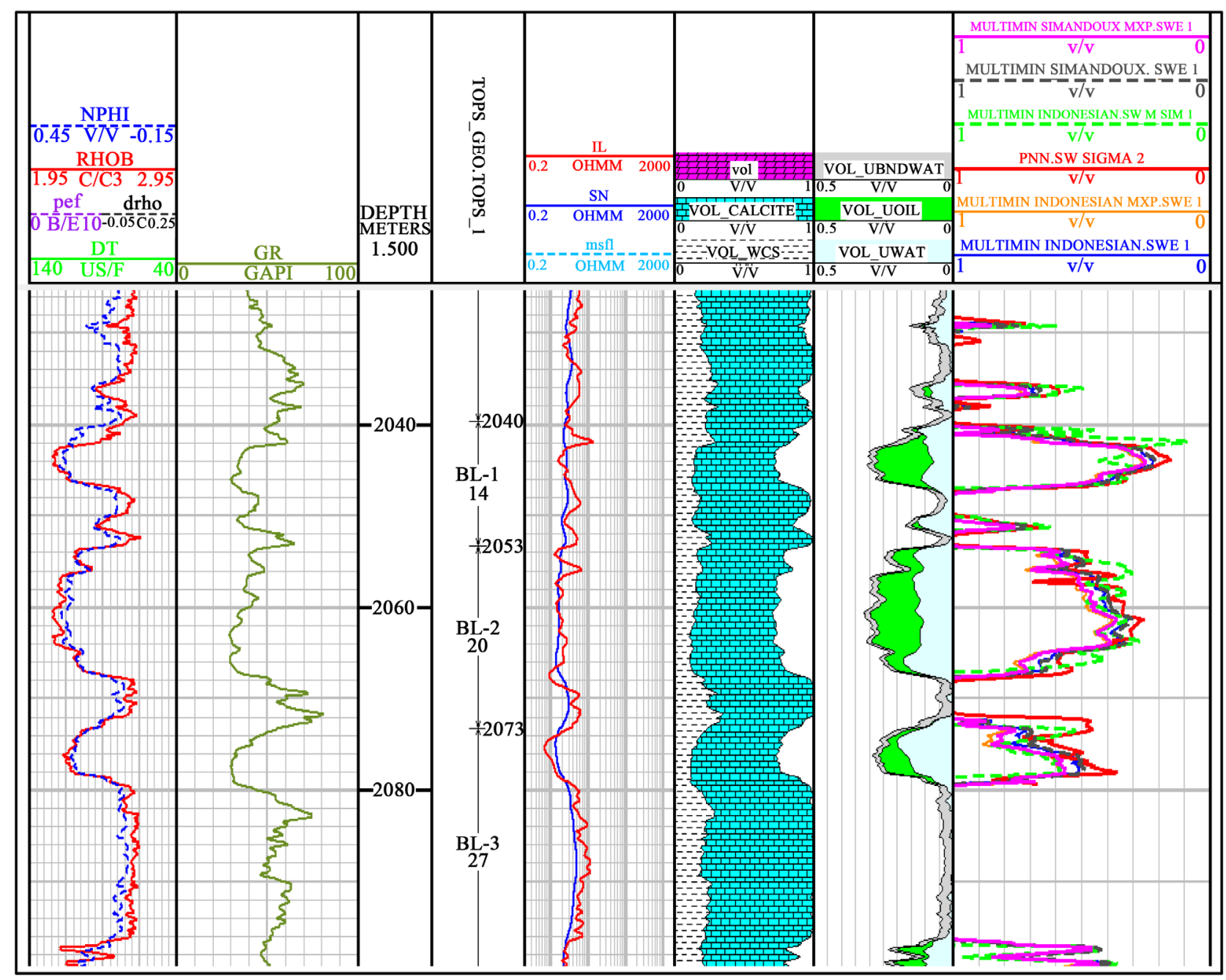

Figure 6. Integrated analysis on the water saturation based on conventional logs and sigma. According sigma logs and evaluation of resistivity logs, water saturation in 3 zones were defined. Water saturation varies from $42 \%, 34 \%$ and $45 \%$ in reservoirs zones respectively.

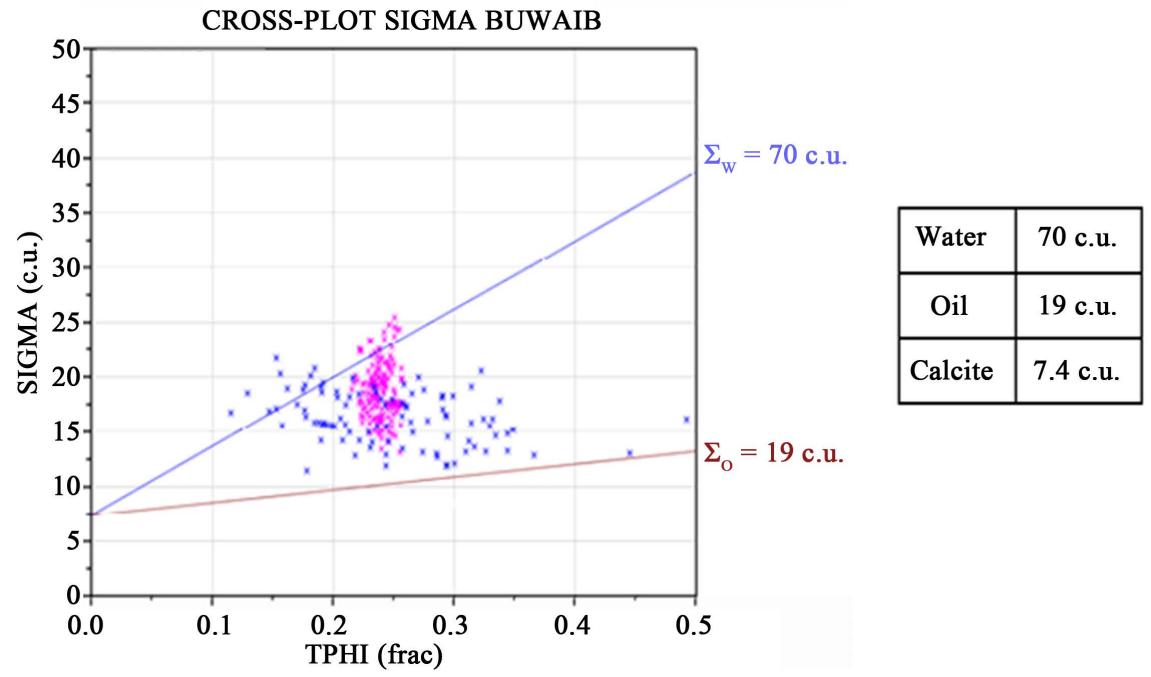

Figure 7. Sigma vs. TPHI cross plot for Buwaib FM. 


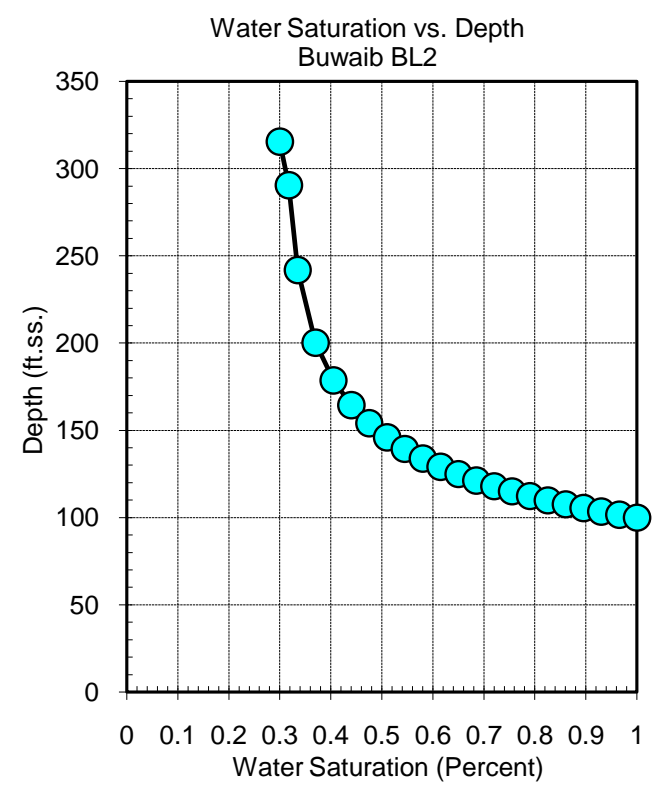

Figure 8. Demonstrates the response water saturation using capillary data in BL2.

sigma capture cross section log reading. Sigma log of X3 interval in Well-1 showed low water saturation compared to conventional resistivity-based water saturation. Capillary pressure-saturation in Figure 8 shows good oil saturation which is consistent with sigma. Finally water saturation estimated $42 \%, 34 \%$ and $40 \%$ in BL1, BL2 and BL3, Table 2. The section was evaluated based $\mathrm{m}=2, \mathrm{n}=2$ and Rw $0.023 \mathrm{ohm} \cdot \mathrm{m}$.

\section{Conclusion}

The Neocomian Buwaib Formation in the Salman Field is recognized as a Low resistivity Pay Zone (LRPZ). The response of resistivity logs is less than $1 \mathrm{ohm} \cdot \mathrm{m}$ in pay zones. The reservoir was divided into 3 units including BL1, BL2 and BL3. Based on geological studies 8 facies were defined that the porous, lithocodium-bearing facies show best quality reservoir. Paramagnetic minerals such as pyrite have the capability to reduce the log resistivity reading. XRD and standard petrophysical cross plots show that dispersed clay types and conductive minerals like pyrite are most reasonable for LRP reservoir. Montmorillonite and Kaolinite along with Illite are main clays types and Montmorillonite has high CEC (Cation exchange capacity) and greater impact on lowering resistivity. Formation was subjected to different diagenetic processes with variable intensities. Reservoir quality is under digenetic process such as pyritization, micritization and bioturbation. Lønøy method addresses pore throat sizes which contain inter crystalline porosity, Chalky Limestone, and Mudstone micro porosity. Pore systems are classified at 3 Lucia and pore size varies from 4 to 20 micron, for defying water saturation was used sigma logs and Capillary data to do quality control. Some constraints were defined to extract reliable water saturation. In BL1, BL2 and BL3 respectively water saturation reach to $42 \%, 34 \%$, and $40 \%$. 
Table 2. Net calculation for reservoir.

\begin{tabular}{cccc}
\hline Layers & Net $(\mathrm{ft})$ & Phi $(\%)$ & Sw (\%) \\
\hline BL1 & 20 & 23.0 & 42 \\
BL2 & 41.3 & 23.3 & 34 \\
BL3 & 19 & 21.2 & 42 \\
\hline
\end{tabular}

\section{Acknowledgements}

The authors would like to acknowledge, with deep appreciation and gratitude, invaluable help and give advices of the associate and assistant Professors of Department of Geology, Basic Science Faculty, North Tehran branch, Islamic Azad University, Tehran, Iran. This work is supported by Iranian offshore oil company and Research department that I am so grateful of experts of Iranian Offshore Oil Company for providing required data and all facilities.

\section{References}

[1] Boyd, A., Darling, H. and Tabanou, J. (1995) The Lowdown on Low-Resistivity Pay. Oilfield Review, 7, 4-18.

[2] Souvick, S. (2003) Low-Resistivity Pay (LRP): Ideas for Solution. Nigeria Annual International Conference and Exhibition, 4-6 August 2003, Abuja, 4-18.

[3] Adedapo, A. and Ayham, A. (2017) A Cohesive Approach at Estimating Water Saturation in a Low-Resistivity Pay Carbonate Reservoir and Its Validation. Journal of Petroleum Exploration and Production Technology, 57, 306-320.

[4] Obeidi, A., Al Aryani, F. and Al Amoudi, M. (2010) Developed Approach for Better Understanding of Low Resistivity Pay Carbonate Reservoirs. Abu Dhabi International Petroleum Exhibition and Conference, 1-4 November 2010, Abu Dhabi, 12. https://doi.org/10.2118/137663-MS

[5] Griffiths, R., Carnegie, A., Gyllensten, A., Ribeiro, M.T., Prasodjo, A. and Sallam, Y. (2006) Evaluation of Low Resistivity Pay in Carbonates-A Breakthrough. Society of Petrophysicists and Well-Log Analysts. SPWLA 47 th Annual Logging Symposium, 4-7 June 2006, Veracruz, 11.

[6] Alsharhan, A.S. (2014) Petroleum systems in the Middle East. In: Rollinson, H.R., Searle, M.P., Abbasi, A.I., Al-Lazki, A.I. and Al Kindi, M.H., Eds., Tectonic Evolution of the Oman Mountains, v. 392, Geological Society, London, 361-408. https://doi.org/10.1144/SP392.19

[7] Dunham, R.J. (1962) Classification of Carbonate Rocks According to Depositional Texture. In: Ham, W.E., Ed., Classification of Carbonate Rocks, AAPG, Tulsa, 108-121.

[8] Flügel, E. (2009) Microfacies of Carbonate Rocks: Microfacies of Carbonate Rocks. Springer, Berlin, $976 \mathrm{p}$.

[9] Lønøy, A. (2006) Making Sense of Carbonate Pore System. AAPG Bulletin, 90, 1381-1405. https://doi.org/10.1306/03130605104

[10] Lucia, J. (2007) Carbonate Reservoir Characterization. Springer, Berlin, 332 p. 
Submit or recommend next manuscript to SCIRP and we will provide best service for you:

Accepting pre-submission inquiries through Email, Facebook, LinkedIn, Twitter, etc. A wide selection of journals (inclusive of 9 subjects, more than 200 journals)

Providing 24-hour high-quality service

User-friendly online submission system

Fair and swift peer-review system

Efficient typesetting and proofreading procedure

Display of the result of downloads and visits, as well as the number of cited articles Maximum dissemination of your research work

Submit your manuscript at: http://papersubmission.scirp.org/

Or contact ojg@scirp.org 